\title{
An effective preparation method of composite photocatalysts for hydrogen evolution using an organic photosensitizer and metal particles assembled on alumina-silica
}

Yusuke Yamada, Hideyuki Tadokoro and Shunichi Fukuzumi

\begin{tabular}{|c|l|}
\hline Citation & Catalysis Today, 278(2): 303-311 \\
\hline Issue Date & $2016-12-1$ \\
\hline Type & Journal Article \\
\hline $\begin{array}{c}\text { Textversion } \\
\text { Supplementary } \\
\text { data }\end{array}$ & author \\
\hline Rights & $\begin{array}{l}\text { C } 2016 \text { Elsevier B.V. This manuscript version is made available under the } \\
\text { This is the accepted manuscript version. The article has been published in final } \\
\text { form at } \text { https://doi.org/10.1016/j.cattod.2016.01.018 } . ~\end{array}$ \\
\hline DOI & $10.1016 /$ j.cattod.2016.01.018 \\
\hline
\end{tabular}

\author{
Self-Archiving by Author(s) \\ Placed on: Osaka City University
}




\section{An Effective Preparation Method of Composite Photocatalysts for Hydrogen Evolution Using an Organic Photosensitizer and Metal Particles Assembled on Alumina-Silica}

Yusuke Yamada ${ }^{\mathrm{a}, *}$, Hideyuki Tadokoro ${ }^{\mathrm{b}}$, and Shunichi Fukuzumi ${ }^{\mathrm{c}, \mathrm{d}, *}$

${ }^{a}$ Department of Applied Chemistry and Bioengineering, Graduate School of Engineering, Osaka City University, 3-3-138 Sugimoto, Sumiyoshi-ku, Osaka 558-8585, Japan

${ }^{b}$ Department of Material and Life Science, Graduate School of Engineering, Osaka University, ALCA and SENTAN, Japan Science and Technology Agency (JST), Suita, Osaka 565-0871, Japan

${ }^{c}$ Faculty of Science and Engineering, Meijo University, ALCA and SENTAN, Japan Science and Technology Agency (JST), Nagoya, Aichi 468-0073, Japan

${ }^{\mathrm{d}}$ Department of Chemistry and Nano Science, Ewha Womans University, Seoul 120-750, Korea

* To whom correspondence should be addressed.

E-mail: ymd@a-chem.eng.osaka-cu.ac.jp; fukuzumi@chem.eng.osaka-u.ac.jp 


\section{Abstract}

Composite catalysts for photocatalytic hydrogen $\left(\mathrm{H}_{2}\right)$ evolution were prepared by loading an organic electron donor-acceptor linked dyad [2-phenyl-4-(1-naphthyl)quinolinium ion, $\mathrm{QuPh}^{+}-$ $\mathrm{NA}]$ as an organic photosensitizer and $\mathrm{Pt}$ or $\mathrm{Cu}$ particles as $\mathrm{H}_{2}$-evolution catalysts on aluminasilica. The composite catalysts loading Pt particles were prepared by two different methods; first, Pt particles were deposited by reduction of $\mathrm{PtCl}_{6}{ }^{2-}$ owing to photocatalysis of $\mathrm{QuPh}^{+}-\mathrm{NA}$ supported on alumina-silica (PD method), and second, alumina-silica was impregnated with the $\mathrm{PtCl}_{6}{ }^{2-}$ and calcined, and then $\mathrm{QuPh}^{+}-\mathrm{NA}$ was loaded on the Pt/alumina-silica by a cation exchange method (IMP method). When a composite catalyst was prepared by the IMP method, a high Pt-loading amount of $4.2 \mathrm{wt} \%$ was necessary to achieve the highest $\mathrm{H}_{2}$-evolution rate of $0.27 \mu \mathrm{mol} \mathrm{h} \mathrm{h}^{-1}$. On the other hand, a composite catalyst prepared by the PD method exhibited three times faster $\mathrm{H}_{2}$ evolution $\left(0.83 \mu \mathrm{mol} \mathrm{h}^{-1}\right)$ even though the loading amount of Pt was as low as $0.4 \mathrm{wt} \%$. The activity of composite catalysts prepared by the PD method highly depends on the electric charges of precursors for Pt particles. A composite catalyst prepared with positively charged $\mathrm{Pt}\left(\mathrm{NH}_{3}\right)_{4}{ }^{2+}$ as a precursor of Pt particles exhibited low catalytic activity with the $\mathrm{H}_{2}$ evolution rate of $0.10 \mu \mathrm{mol} \mathrm{h}{ }^{-1}$, which is significantly lower than the rate $\left(0.27 \mu \mathrm{mol} \mathrm{h}^{-1}\right)$ for the composite catalyst prepared with $\mathrm{PtCl}_{6}{ }^{2-}$. However, such precursor-dependence was not observed for composite catalysts employing $\mathrm{Cu}$ particles as an $\mathrm{H}_{2}$-evolution catalyst, because the $\mathrm{Cu}$ precursors are more labile than the Pt precursors in a reaction solution. The electrostatic interaction between the precursors of metal particles and negatively charged surfaces of aluminasilica should be taken into account to construct efficient $\mathrm{H}_{2}$-evolution catalysts.

Keywords: Photocatalyst; Hydrogen production; Preparation method; Organic photosensitizer 


\section{Introduction}

Utilization of solar energy to produce high-energy compounds such as hydrogen $\left(\mathrm{H}_{2}\right)$ attracts much attention to realize environmentally benign and sustainable society [1-5]. Two typical photocatalytic $\mathrm{H}_{2}$-evolution systems have been extensively studied. One is a system using a semiconductor photocatalyst, which can split water to $\mathrm{H}_{2}$ and $\mathrm{O}_{2}$ under UV irradiation [6-9]. The fine-tuning of the bandgap of a metal-oxide semiconductor photocatalyst by doping nitrogen or sulfur has enabled to utilize visible light for the photocatalytic $\mathrm{H}_{2}$ production from water [1011]. However, the quantum efficiency under visible light has remained low for any practical applications. The other system for photocatalytic $\mathrm{H}_{2}$ production utilizes metal complexes or organic molecules as photosensitizers together with a water reduction catalyst in homogeneous systems for efficient utilization of visible light [12-23]. In these systems sacrificial electron donors are required for the $\mathrm{H}_{2}$ evolution. To replace sacrificial electron donors to water as an electron donor, combination of the $\mathrm{H}_{2}$-evolution systems with water oxidation catalysts is necessary [24-33]. However, simple combination of water oxidation catalysts with water reduction catalysts in a solution results in the reversed flow of electrons from the reduced water reduction catalysts to the oxidized water oxidation catalysts. The undesired back electron transfer can be avoided by rational arrangement of photosensitizers and catalysts for water oxidation and reduction on a suitable support, where the movement of each component can be suppressed. Development of procedure to prepare composite catalysts having rational arrangement of each component on the support is crucial to construct $\mathrm{H}_{2}$-evolution systems utilizing visible light.

Before constructing a fully assembled catalyst, we have combined an organic photosensitizer [2-phenyl-4-(1-naphthyl)quinolinium ion, $\mathrm{QuPh}^{+}-\mathrm{NA}$ ] and a water reduction catalyst $(\mathrm{Pt}, \mathrm{Cu}$, etc) on alumina-silica, which successfully exhibited photocatalytic activity for the $\mathrm{H}_{2}$ evolution 
employing oxalate as an electron donor [34]. $\mathrm{QuPh}^{+}-\mathrm{NA}$ is an electron donor-acceptor linked dyad which possesses not only an extremely long lifetime of an electron-transfer state but also strong oxidizing and reducing abilities under photoirradiation [35]. The chemical structure of $\mathrm{QuPh}^{+}-\mathrm{NA}$ used in this study and the overall photocatalytic cycle for $\mathrm{H}_{2}$ evolution are depicted in Scheme 1 [36-42]. The catalytic cycle starts from photoexcitation of $\mathrm{QuPh}^{+}-\mathrm{NA}$ in which

Scheme 1. (a) Structure of $\mathrm{QuPh}^{+}-\mathrm{NA}$ and (b) the overall photocatalytic cycle for $\mathrm{H}_{2}$ evolution on a composite catalyst using $\mathrm{QuPh}^{+}-\mathrm{NA}$ and metal nanoparticles on alumina-silica

(a)

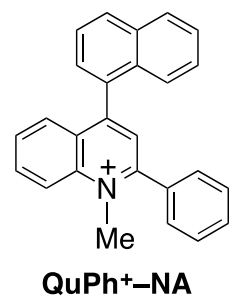

(b)

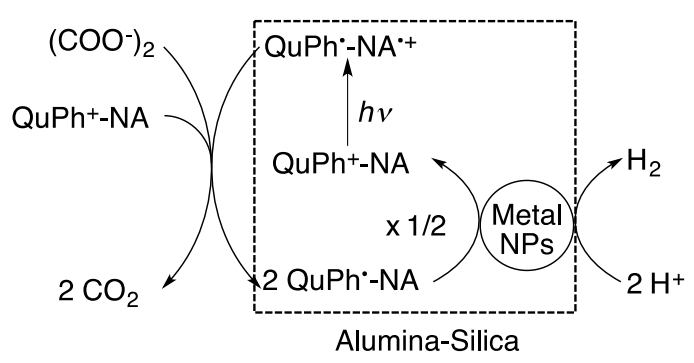

electron transfer from the NA moiety to the singlet excited state of the $\mathrm{QuPh}^{+}$moiety occurs to produce the electron-transfer state $\left(\mathrm{QuPh}^{\bullet}-\mathrm{NA}^{\cdot+}\right)$. Then, electron transfer from oxalate to $\mathrm{QuPh}{ }^{\circ}-$ $\mathrm{NA}^{\cdot+}$ occurs to produce $\mathrm{CO}_{2}$ and $\mathrm{CO}_{2}{ }^{--}$and $\mathrm{QuPh}{ }^{-}-\mathrm{NA} . \mathrm{CO}_{2}{ }^{--}$can transfer an electron to $\mathrm{QuPh}^{+}-$ NA to produce $\mathrm{CO}_{2}$ and $\mathrm{QuPh}{ }^{-}-\mathrm{NA}$. Two equivalents of $\mathrm{QuPh}{ }^{-} \mathrm{NA}$ thus produced can inject two electrons to metal nanopatricles to produce $\mathrm{H}_{2}$ by reduction of two protons. In our previous work, combined catalysts were successfully prepared by the following two-step route (PD method): $\mathrm{QuPh}^{+}-\mathrm{NA}$ was first loaded on alumina-silica $\left(\mathrm{QuPh}^{+}-\mathrm{NA} @ \mathrm{Al}_{2} \mathrm{O}_{3}-\mathrm{SiO}_{2}\right)$ by the cation exchange method and then, $\mathrm{Pt}$ or $\mathrm{Cu}$ particles were supported on the $\mathrm{QuPh}^{+}-\mathrm{NA} @ \mathrm{Al}_{2} \mathrm{O}_{3}-\mathrm{SiO}_{2}$ by the reduction of $\mathrm{PtCl}_{6}{ }^{2-}$ or $\mathrm{CuCl}_{2}$ in situ with photogenerated $\mathrm{QuPh}{ }^{-}-\mathrm{NA}$ [34]. However, preparation conditions to achieve highly active composite catalysts have yet to be clarified in terms of choices of precursors, and nanostructures and morphologies of silica-alumina supports, etc. 
We report herein the effect of preparation conditions of the catalysts composed of aluminasilica loading $\mathrm{QuPh}^{+}-\mathrm{NA}$ and $\mathrm{Pt}$ particles on their catalysis for photocatalytic $\mathrm{H}_{2}$ evolution using oxalate as a sacrificial electron donor. Other than the PD method, the impregnation method (IMP method), in which alumina-silica was impregnated with $\mathrm{Pt}$ and then loading $\mathrm{QuPh}^{+}-\mathrm{NA}$ by the cation-exchange method, was examined to construct a composite catalyst. Also, various types of Pt complexes and Pt salts were examined as precursors of Pt particles for the PD method. Additionally, nanostructures and morphologies of alumina-silica supports were optimized for further improvement in the photocatalytic reactivity. Suitable preparation conditions were also investigated for a composite catalyst employing $\mathrm{Cu}$ particles, which has been less studied as an $\mathrm{H}_{2}$ evolution catalyst.

\section{Experimental section}

\subsection{Catalyst preparation}

All chemicals were obtained from chemical companies and used without further purification. $\mathrm{K}_{2} \mathrm{Pt}^{\mathrm{IV}} \mathrm{Cl}_{6}, \quad \mathrm{Pt}^{\mathrm{II}}\left(\mathrm{NH}_{3}\right)_{4} \mathrm{Cl}_{2}, \quad \mathrm{~K}_{2} \mathrm{Cu}^{\mathrm{II}} \mathrm{Cl}_{4} \cdot 2 \mathrm{H}_{2} \mathrm{O}, \quad \mathrm{Ru}^{\mathrm{III}} \mathrm{Cl}_{3}, \quad \mathrm{Co}^{\mathrm{II}}\left(\mathrm{NO}_{3}\right)_{2}, \quad \mathrm{Fe}^{\mathrm{II}} \mathrm{SO}_{4} \cdot 7 \mathrm{H}_{2} \mathrm{O}$, cetyltrimethylammonium bromide (CTAB), sodium aluminate, acetic acid, hydrochloric acid and sodium hydroxide were obtained from Wako Pure Chemical Industries. $\mathrm{K}_{2} \mathrm{Pt}^{\mathrm{II}} \mathrm{Cl}_{4}$ was purchased from Sigma-Aldrich. An aqueous solution of ammonia (28\%) and $\beta$-nicotinamide adenine dinucleotide disodium salt (reduced form) (NADH) were obtained from Tokyo Chemical Industry. Tetraethyl orthosilicate (TEOS) was delivered by Shin-Etsu Chemical. 2-Phenyl-4-(1naphthyl)quinolinium $\left(\mathrm{QuPh}^{+}-\mathrm{NA}\right)$ perchlorate was synthesized by a literature method [35]. Purified water was provided by a Millipore MilliQ UV-3 water purification system where the electronic conductance was 18.2 M $\Omega \mathrm{cm}$. Spherical Al-MCM-41 (sAlMCM-41), spherical $\mathrm{Al}_{2} \mathrm{O}_{3}-\mathrm{SiO}_{2}\left(\mathrm{sAl}_{2} \mathrm{O}_{3}-\mathrm{SiO}_{2}\right)$ and unshape-controlled $\mathrm{Al}_{2} \mathrm{O}_{3}-\mathrm{SiO}_{2}\left(\mathrm{uAl}_{2} \mathrm{O}_{3}-\mathrm{SiO}_{2}\right)$ were prepared by 
literature methods [39]. cis-[ $\left.\mathrm{Pt}_{2}\left(\mathrm{NH}_{3}\right)_{2}\left(\mu-\mathrm{C}_{2} \mathrm{H}_{4} \mathrm{NO}\right)_{2}\right]\left(\mathrm{ClO}_{4}\right)_{2},\left[\mathrm{Cu}(\mathrm{bpy})_{2}\right]\left(\mathrm{NO}_{3}\right)_{2} \cdot 0.75 \mathrm{H}_{2} \mathrm{O}$ and $\left[\mathrm{Cu}(\mathrm{MeObpy})_{2}\right]\left(\mathrm{NO}_{3}\right)_{2}$ were also synthesized by literature methods [43].

Unshape-controlled AlMCM-41 (uAlMCM-41) was prepared by the following procedure. To an aqueous solution $(1.0 \mathrm{~L})$ containing $\mathrm{NaOH}(8.4 \mathrm{~g}, 0.21 \mathrm{~mol})$ and CTAB $(18.4 \mathrm{~g}, 44.4$ mmol) was added dropwise of TEOS (87.5 g, $418 \mathrm{mmol}$ ) with vigorous stirring for $1 \mathrm{~h}$ at $35^{\circ} \mathrm{C}$. The solution was further stirred for $30 \mathrm{~min}$ at the temperature. Then, an aqueous solution (100 $\mathrm{mL})$ of sodium aluminate $(0.48 \mathrm{~g}, 7.9 \mathrm{mmol})$ was slowly added to the solution and stirred for $4 \mathrm{~h}$ at room temperature. The obtained white precipitate was filtered, washed with water and dried at $60{ }^{\circ} \mathrm{C}$. The precipitate was calcined at $500{ }^{\circ} \mathrm{C}$ for $6 \mathrm{~h}$ with a ramp rate of $1{ }^{\circ} \mathrm{C} \mathrm{min}^{-1}$.

Unshape-controlled $\mathrm{Al}_{2} \mathrm{O}_{3}-\mathrm{SiO}_{2}$ was prepared by the surface alumination of unshaped silica powder. Silica powder $(10-20 \mathrm{~nm}, 3.0 \mathrm{~g}, 50 \mathrm{mmol})$ was suspended in an aqueous solution (150 $\mathrm{mL})$ of sodium aluminate $(0.19 \mathrm{mg}, 3.1 \mathrm{mmol})$ with magnetic stirring at room temperature for 24 h. The obtained powder was collected by centrifugation, washed with water, and dried at $60{ }^{\circ} \mathrm{C}$. The obtained white powder was calcined at $550{ }^{\circ} \mathrm{C}$ for $5 \mathrm{~h}$ with a ramp rate of $1{ }^{\circ} \mathrm{C} \min ^{-1}$.

sAlMCM-41 loading Pt (Pt/sAlMCM-41) was prepared by an impregnation method. sAlMCM-41 $(500 \mathrm{mg})$ was immersed in an ethanol solution $(1.0 \mathrm{~mL})$ containing a calculated amount of $\mathrm{K}_{2} \mathrm{PtCl}_{6}$ on an ultrasonicator for $30 \mathrm{~min}$ at room temperature. The powder was dried at $60{ }^{\circ} \mathrm{C}$ in air and calcined at $500{ }^{\circ} \mathrm{C}$ for $4 \mathrm{~h}$ with a ramp rate of $2{ }^{\circ} \mathrm{C} \mathrm{min}^{-1}$. The loading amount of Pt was determined by X-ray fluorescence measurements performed with a Rigaku ZSX-100e.

Alumina-silica loading $\mathrm{QuPh}^{+}-\mathrm{NA}$ was prepared by the cation-exchange method. An acetonitrile solution $(10 \mathrm{~mL})$ of $\mathrm{QuPh}^{+}-\mathrm{NA}(6.0 \mathrm{mM}$ or $2.0 \mathrm{mM})$ was slowly added to an aqueous suspension $(10 \mathrm{~mL})$ containing alumina-silica $(200 \mathrm{mg})$ with gentle magnetic stirring. After keeping for a certain time at room temperature, the supernatant was removed and dried at 
$60{ }^{\circ} \mathrm{C}$. The amount of $\mathrm{QuPh}^{+}-\mathrm{NA}$ was determined by the decrease of absorbance at $333 \mathrm{~nm}$ originated from $\mathrm{QuPh}^{+}-\mathrm{NA}$ ion. The same procedure was applied for loading $\mathrm{QuPh}^{+}-\mathrm{NA}$ on Pt/sAlMCM to achieve a composite catalyst (IMP method). Composite catalysts prepared by the PD method were obtained by photoirradiation $(\lambda>340 \mathrm{~nm})$ of suspension containing aluminasilica loading $\mathrm{QuPh}^{+}-\mathrm{NA}, \mathrm{K}_{2} \mathrm{PtCl}_{6}$ and oxalic acid. The obtained catalysts were used for the catalysis measurements without isolation.

\subsection{Catalyst characterization}

Transmission electron microscopy (TEM) was used for the determination of the sizes and shapes of catalysts. Bright field images were obtained by a JEOL JEM-2100 that has a thermal field emission gun with an accelerating voltage of $200 \mathrm{kV}$. The observed samples were prepared by dropping a suspension of catalysts, allowing the solvent to evaporate and then scooped up with an amorphous carbon supporting film. Nitrogen adsorption-desorption at $77 \mathrm{~K}$ was performed with a Belsorp-mini (BEL Japan, Inc.) within a relative pressure range from 0.01 to $101.3 \mathrm{kPa}$. A sample mass of $\sim 100 \mathrm{mg}$ was used for adsorption analysis after pretreatment at 120 ${ }^{\circ} \mathrm{C}$ for $1 \mathrm{~h}$ under vacuum conditions and kept in $\mathrm{N}_{2}$ atmosphere until $\mathrm{N}_{2}$-adsorption measurements. The samples were exposed to a mixed gas of $\mathrm{He}$ and $\mathrm{N}_{2}$ with a programmed ratio and adsorbed amount of $\mathrm{N}_{2}$ was calculated from the change of pressure in a cell after reaching the equilibrium. The surface area of each catalyst was determined by the Brunauer-EmmettTeller (BET) method for multiple $\mathrm{N}_{2}$ adsorption amounts under the conditions of partial pressure less than 0.3 . The sizes of mesopores of alumina-silica (AlMCM-41 and sAlMCM-41) were determined by the MP method. Powder X-ray diffraction patterns were recorded by a Rigaku Miniflex 600. Incident X-ray radiation was produced by a Cu X-ray tube, operating at $40 \mathrm{kV}$ and $15 \mathrm{~mA}$ with $\mathrm{Cu} K \alpha$ radiation of $1.54 \AA$. The scanning rate was $2^{\circ} \min ^{-1}$ from $5^{\circ}$ to $80^{\circ}$ in $2 \theta$. 


\subsection{Catalysis measurements}

A typical procedure for photocatalytic $\mathrm{H}_{2}$ evolution is as follows: an aqueous phthalate buffer (50 mM, pH 4.5, $2.0 \mathrm{~mL})$ containing $\mathrm{QuPh}^{+}-\mathrm{NA} @$ sAlMCM-41 composite $\left(\mathrm{QuPh}^{+}-\mathrm{NA}\right.$ : $0.22 \mathrm{mM})$, and $\mathrm{K}_{2} \mathrm{PtCl}_{6}(0.027 \mathrm{mM})$ was flushed with $\mathrm{N}_{2}$ gas in dark. The suspension was then photoirradiated for a certain time with a xenon lamp (Ushio Optical, Model X SX-UID 500X AMQ) through a color filter glass (Asahi Techno Glass L39) transmitting $\lambda>340 \mathrm{~nm}$ at room temperature. After 1 min stirring in the dark, gas in a headspace was analyzed by Shimadzu GC14B gas chromatography (detector: $\mathrm{TCD}$, column temperature: $50^{\circ} \mathrm{C}$, column: active carbon with the particle size $60-80$ mesh, carrier gas: $\mathrm{N}_{2}$ gas) to quantify evolved $\mathrm{H}_{2}$.

\section{Results and discussion}

3.1. Catalysis of composite catalysts loading Pt by an impregnation and a photodeposition method for photocatalytic $\mathrm{H}_{2}$ evolution

Composite catalysts loading an organic photosensitizer [2-phenyl-4-(1-naphthyl)quinolinium ion, $\left.\mathrm{QuPh}^{+}-\mathrm{NA}\right]$ and an $\mathrm{H}_{2}$-evolution catalyst, $\mathrm{Pt}$ particles, on alumina-silica for photocatalytic $\mathrm{H}_{2}$-evolution were prepared by two different methods: an IMP method and a PD method. In the IMP method, composite catalysts were prepared by impregnation of alumina-silica with an aqueous solution of $\mathrm{K}_{2} \mathrm{PtCl}_{6}$ as a precursor, followed by calcination, and then $\mathrm{QuPh}^{+}-\mathrm{NA}$ was loaded by the cation-exchange method on the calcined alumina-silica loading Pt. In the PD method, $\mathrm{QuPh}{ }^{+}-\mathrm{NA}$ was supported on alumina-silica $\left(\mathrm{QuPh}^{+}-\mathrm{NA} @\right.$ alumina-silica $)$ by the cation-exchange method and then, the $\mathrm{QuPh}^{+}-\mathrm{NA} @$ alumina-silica was suspended in an aqueous phthalate buffer ( $\mathrm{pH} 4.5$ ) containing $\mathrm{K}_{2} \mathrm{PtCl}_{6}$ and oxalic acid. $\mathrm{Pt}$ particles were deposited on the $\mathrm{QuPh}^{+}-\mathrm{NA} @$ alumina-silica by photoirradiation of the suspension. Pt particles deposited on 
$\mathrm{QuPh}^{+}-\mathrm{NA} @$ alumina-silica was confirmed by the TEM images shown in Fig. 1, in which the sizes of the Pt particles were smaller than $1 \mathrm{~nm}$. The concentration of Pt deposited on
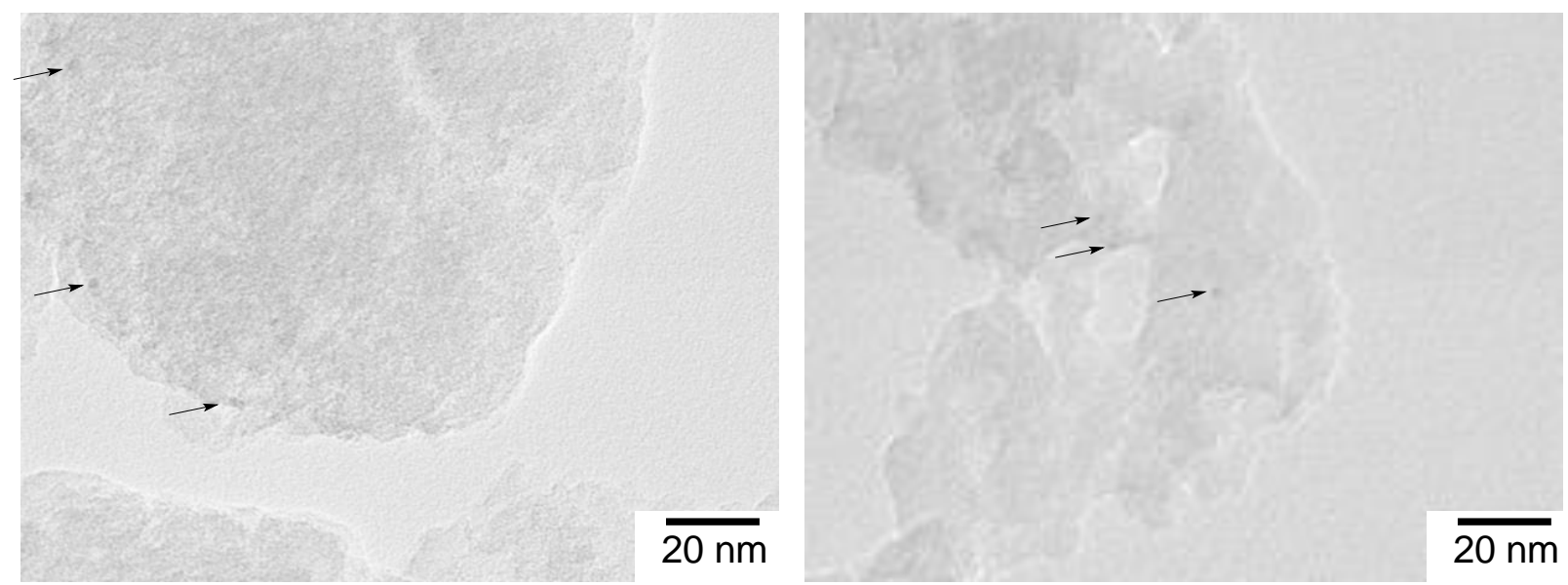

Fig. 1. TEM images of $\mathrm{QuPh}^{+}-\mathrm{NA} @$ sAlMCM-41 loading Pt particles by the photodeposition method. Relatively large Pt nanoparticles are indicated by the arrows.

$\mathrm{QuPh}^{+}-\mathrm{NA} / \mathrm{sAlMCM}-41$ after the photocatalytic reaction was determined to be $0.3( \pm 0.1)$ wt $\%$ in the solution containing $0.027 \mathrm{mM} \mathrm{K}_{2} \mathrm{PtCl}_{6}$ by XRF measurements, where the maximum concentration of $\mathrm{Pt}$ is $0.21 \mathrm{wt} \%$. Thus, almost all $\mathrm{Pt}$ ions were converted to $\mathrm{Pt}$ particles.

Photocatalytic $\mathrm{H}_{2}$ evolution was performed by photoirradiation $(\lambda>340 \mathrm{~nm})$ of an aqueous phthalate buffer $(50 \mathrm{mM}, \mathrm{pH} 4.5,2.0 \mathrm{~mL})$ containing oxalate $(50 \mathrm{mM})$ and the catalysts loading various amounts of $\mathrm{Pt}\left(\left[\mathrm{QuPh}^{+}-\mathrm{NA}\right]: 0.22 \mathrm{mM},[\mathrm{Pt}]: 0.013-0.55 \mathrm{mM}\right)$ prepared by the IMP method. The $\mathrm{H}_{2}$-evolution rate increased in proportion to the loading amount of $\mathrm{Pt}$ up to $2.1 \mathrm{wt} \%$ ([Pt]: $0.27 \mathrm{mM}$ in the reaction solution) as shown in Fig. 2a. No further increase in the $\mathrm{H}_{2}-$ evolution rate was observed by increasing the loading amount of Pt to $4.2 \mathrm{wt} \%$ ([Pt]: $0.55 \mathrm{mM}$ ). The saturation behavior against the loading amount of Pt resulted from enough high surface density of Pt particles at $2.1 \mathrm{wt} \%$ to be interacted with all the $\mathrm{QuPh}^{+}-\mathrm{NA}$ loaded on the aluminasilica. 
(a)

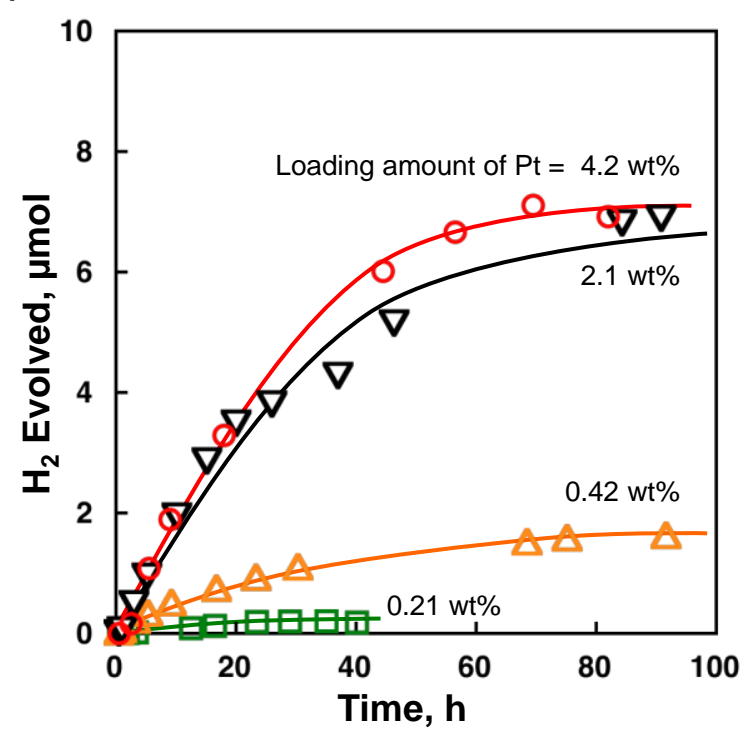

(b)

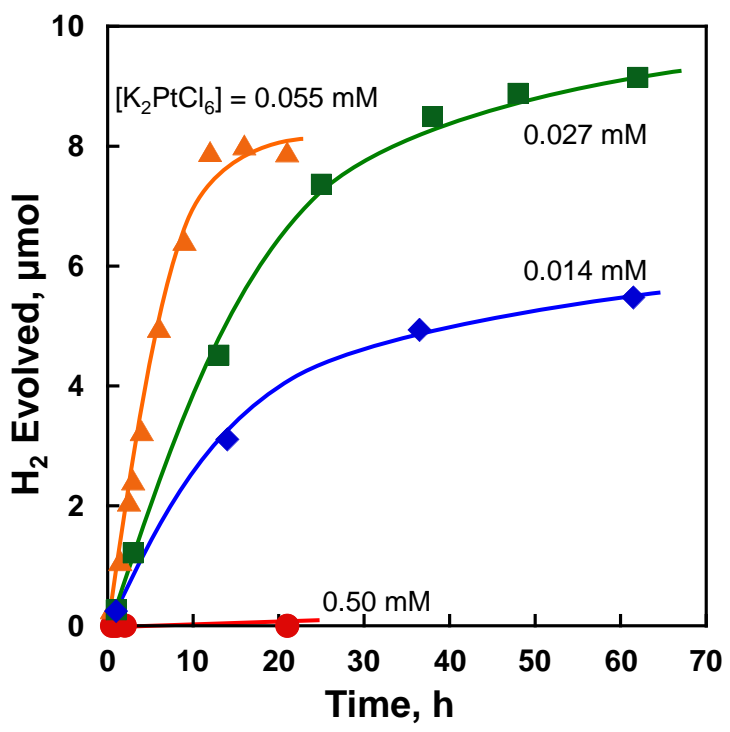

Fig. 2. Time courses of the photocatalytic $\mathrm{H}_{2}$ evolution performed by photoirradiation $(\lambda>340$ $\mathrm{nm})$ of a deaerated phthalate buffer $(\mathrm{pH} 4.5,2.0 \mathrm{~mL})$ containing $(\mathrm{COONa})_{2}(50 \mathrm{mM})$ and various Pt-loaded $\mathrm{QuPh}^{+}-\mathrm{NA} @$ alumina-silica (sAlMCM-41) catalysts ( 3.0 mg, [QuPh $\left.{ }^{+}-\mathrm{NA}\right]: 0.22$ $\mathrm{mM}$ ) prepared by the impregnation (IMP) method and the photodeposition (PD) method. (a) IMP method: Pt loadings [0.21 wt\% (green open square), $0.42 \mathrm{wt} \%$ (orange open triangle), 2.1 wt\% (black open inverted triangle) and $4.2 \mathrm{wt} \%$ (red open circle)] and (b) PD method: the concentrations of $\mathrm{PtCl}_{6}{ }^{2-}$ in solutions $[0.014 \mathrm{mM}$ (blue diamond), $0.027 \mathrm{mM}$ (green square), $0.055 \mathrm{mM}$ (orange triangle) and $0.50 \mathrm{mM}$ (red circle)].

Photocatalytic activity of the composite catalysts prepared by the PD method was also evaluated by the photoirradiation of an aqueous phthalate buffer containing $\mathrm{QuPh}^{+}-\mathrm{NA} /$ aluminasilica, $(\mathrm{COONa})_{2}$ and $\mathrm{K}_{2} \mathrm{PtCl}_{6}$ with various concentrations $(0.018-0.50 \mathrm{mM})$ (Fig. $\left.2 \mathrm{~b}\right)$. The composite catalysts formed in situ under reaction conditions and used without separation from the suspension. The $\mathrm{H}_{2}$-evolution rate was increased to $0.83 \mu \mathrm{mol} \mathrm{h}^{-1}$ by increasing the concentration of $\mathrm{K}_{2} \mathrm{PtCl}_{6}$ up to $0.055 \mathrm{mM}$, which is 10 times larger than that $\left(0.07 \mu \mathrm{mol} \mathrm{h}^{-1}\right)$ for a composite catalyst loading the same amount of Pt by the IMP method $(0.42 \mathrm{wt} \%)$. Turnover numbers of $\mathrm{Pt}$ for $\mathrm{H}_{2}$ evolution were 14 and 73 for composite catalysts loading $\mathrm{Pt}(0.42 \mathrm{wt} \%$ ) by the IMP and PD methods, respectively. Thus, the PD method is the more suitable method to 
achieve an efficient photocatalytic $\mathrm{H}_{2}$-evolution system than the IMP method with a small amount of Pt.

3.2. Precursor effect on $\mathrm{H}_{2}$-evolution catalysis of composite catalysts prepared by the PD method

Catalytic activity of composite catalysts loading Pt by the photodeposition method depends on Pt precursors. Composite catalysts were in situ prepared by the PD method in an aqueous buffer containing oxalate, $\mathrm{QuPh}^{+}-\mathrm{NA} @$ sAlMCM-41 and various Pt precursors ([Pt]: $\left.0.027 \mathrm{mM}\right)$. Time courses of $\mathrm{H}_{2}$ evolution for the reaction systems using various Pt precursors are indicated in Fig. 3. When anionic $\mathrm{PtCl}_{6}{ }^{2-}$ and $\mathrm{PtCl}_{4}{ }^{2-}$ were used as precursors, the initial $\mathrm{H}_{2}$-evolution rates (5 h) were 0.31 and $0.40 \mu \mathrm{mol} \mathrm{h}{ }^{-1}$, respectively. Although the concentration of $\mathrm{Pt}$ is the

(a)

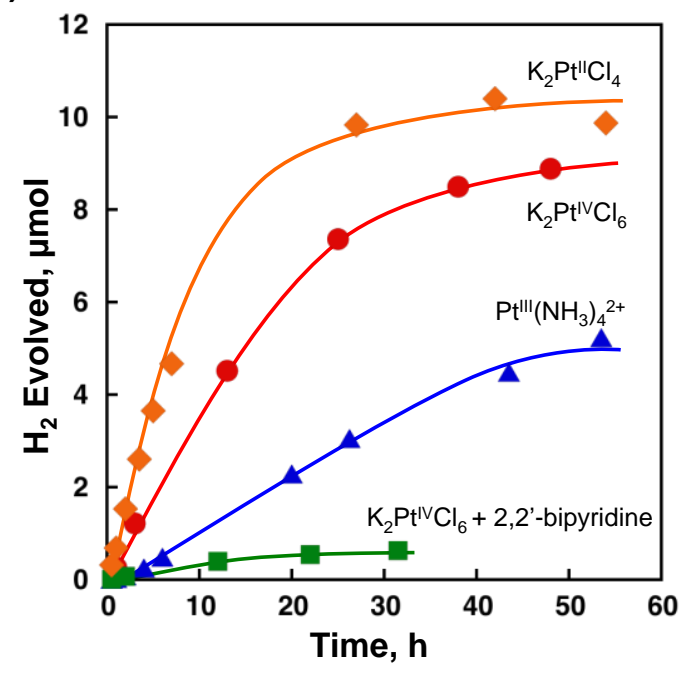

(b)

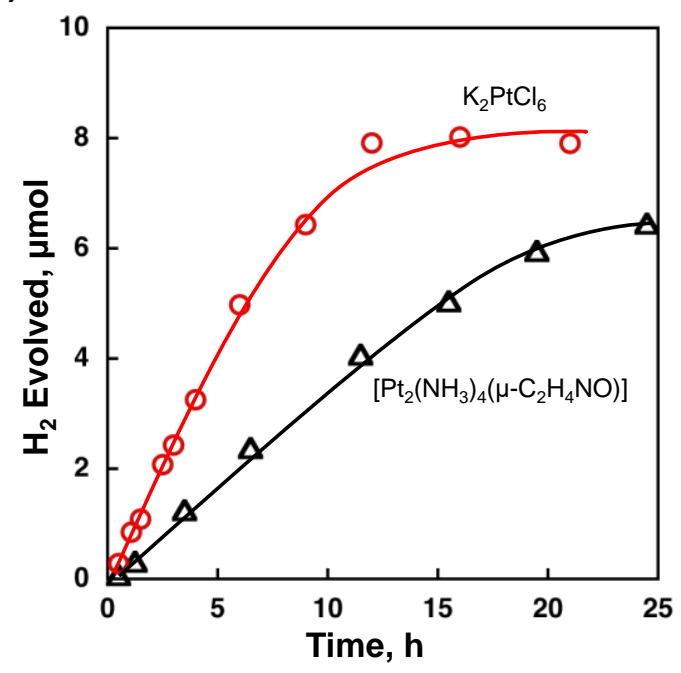

Fig. 3. Time courses of hydrogen evolution by photoirradiation $(\lambda>340 \mathrm{~nm})$ of an aqueous buffer $(2.0 \mathrm{~mL})$ containing oxalate $(50 \mathrm{mM}), \mathrm{QuPh}^{+}-\mathrm{NA} @$ sAlMCM-41 (5.0 mg, [QuPh $\left.{ }^{+}-\mathrm{NA}\right]$ : $0.22 \mathrm{mM}$ ) and various $\mathrm{Pt}$ precursors. Pt precursors were (a) $\mathrm{PtCl}_{6}{ }^{2-}$ (red circle), $\mathrm{PtCl}_{4}{ }^{2-}$ (orange diamond), $\mathrm{Pt}\left(\mathrm{NH}_{3}\right)_{4}{ }^{2+}$ (blue triangle) and $\mathrm{PtCl}_{6}{ }^{2-}$ together with 2,2'-bipyridine $(0.081 \mathrm{mM})$ (green square); $[\mathrm{Pt}]=0.027 \mathrm{mM}$ and (b) $\mathrm{PtCl}_{6}{ }^{2-}$ (red open circle) and cis- $\left[\mathrm{Pt}_{2}\left(\mathrm{NH}_{3}\right)_{4}\left(\mu-\mathrm{C}_{2} \mathrm{H}_{4} \mathrm{NO}\right)\right]$ (black open triangle); $[\mathrm{Pt}]=0.055 \mathrm{mM}$. 
same, slower $\mathrm{H}_{2}$ evolution $\left(0.11 \mu \mathrm{mol} \mathrm{h}^{-1}\right)$ was observed for the reaction systems using positively charged $\mathrm{Pt}\left(\mathrm{NH}_{3}\right)_{4}{ }^{2+}$ as a precursor, suggesting that the electric charges of precursors should be taken into consideration to construct an efficient photocatalytic system. Positively-charged $\mathrm{Pt}\left(\mathrm{NH}_{3}\right)_{4}{ }^{2+}$ has attractive interaction with negatively charged surfaces of alumina-silica where it may be trapped far from the loaded $\mathrm{QuPh}^{+}-\mathrm{NA}$ molecules. Thus, the anionic precursors, i.e. $\mathrm{PtCl}_{6}{ }^{2-}$ and $\mathrm{PtCl}_{4}{ }^{2-}$, which can interact with positively charged $\mathrm{QuPh}^{+}-\mathrm{NA}$ but not with the negatively charged surfaces of alumina-silica, are suitable for construction of an efficient photocatalytic $\mathrm{H}_{2}$-evolution system. When 2,2'-bipyridine (bpy) was added to the reaction solution containing $\mathrm{PtCl}_{6}^{2-}$, only negligible amount of $\mathrm{H}_{2}$ was evolved probably due to the coordination of chelating bpy ligand to $\mathrm{Pt}^{\mathrm{IV}}$ ion strongly preventing the deposition of Pt particles. A significant amount of $\mathrm{H}_{2}$ evolution was observed for a reaction solution containing cis$\left[\mathrm{Pt}_{2}\left(\mathrm{NH}_{3}\right)_{4}\left(\mu-\mathrm{CH}_{2} \mathrm{NO}\right)_{2}\right]$, which has been reported to act as a homogeneous catalyst for $\mathrm{H}_{2}$ evolution (Fig. 3b) [43]. However, the $\mathrm{H}_{2}$ evolution from the reaction system using cis$\left[\mathrm{Pt}_{2}\left(\mathrm{NH}_{3}\right)_{4}\left(\mu-\mathrm{CH}_{2} \mathrm{NO}\right)_{2}\right]$ was slower than that using $\mathrm{PtCl}_{6}{ }^{2-}$. Thus, the deposition of Pt particles in the close vicinity of $\mathrm{QuPh}^{+}-\mathrm{NA}$ is important to achieve efficient $\mathrm{H}_{2}$ evolution.

The effect of concentrations of oxalic acid on $\mathrm{H}_{2}$-evolution rates was examined in the photocatalytic $\mathrm{H}_{2}$ evolution employing catalysts prepared by the $\mathbf{P D}$ method with $\mathrm{K}_{2} \mathrm{PtCl}_{6}$ (Fig. 4). According to the $\mathrm{p} K_{\mathrm{a} 1}(1.2)$ and $\mathrm{p} K_{\mathrm{a} 2}$ (4.3) values of oxalic acid, dianion species of oxalic acid was mainly formed in the buffer with $\mathrm{pH} 4.5$ [44]. The initial $\mathrm{H}_{2}$-evolution rate increased in proportion to the concentration of oxalate dianion up to $25 \mathrm{mM}$. No further increase in the $\mathrm{H}_{2-}$ evolution rate was observed even at a concentration of oxalic acid higher than $25 \mathrm{mM}$, suggesting that the oxalate concentration of $25 \mathrm{mM}$ is enough high to fully reduce photoexcited $\mathrm{QuPh}^{+}-\mathrm{NA}\left(\mathrm{QuPh}^{-}-\mathrm{NA}^{*+}\right)$ under the current reaction conditions. 


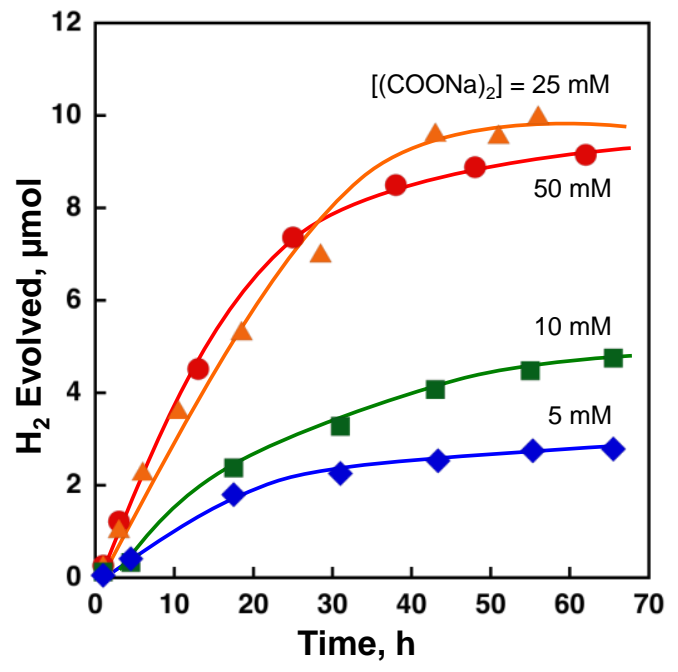

Fig. 4. Time courses of the photocatalytic $\mathrm{H}_{2}$ evolution in various concentrations of $(\mathrm{COONa})_{2}$ (5.0 mM, blue diamond; $10 \mathrm{mM}$, green square; $25 \mathrm{mM}$, orange triangle; $50 \mathrm{mM}$, red circle). $\mathrm{H}_{2}$ evolution was performed under photoirradiation $(\lambda>340 \mathrm{~nm})$ of a deaerated phthalate buffer $(\mathrm{pH}$ 4.5, $2.0 \mathrm{~mL})$ containing $\mathrm{QuPh}^{+}-\mathrm{NA} @ \mathrm{sAlMCM} 41\left(5.0 \mathrm{mg},\left[\mathrm{QuPh}^{+}-\mathrm{NA}\right]=0.22 \mathrm{mM}\right)$ and $(\mathrm{COONa})_{2}(5.0-50 \mathrm{mM})$ with $\mathrm{K}_{2} \mathrm{PtCl}_{6}(0.027 \mathrm{mM})$ at $298 \mathrm{~K}$.

\subsection{Effect of nanostructures and morphologies of alumina-silica supports}

Nanostructures and morphologies of alumina-silica supports effect on the photocatalysis of composite catalysts for $\mathrm{H}_{2}$ evolution. The supports were classified into the following four groups based on the morphology and porosity; spherical alumina-silica with mesopores (sAlMCM-41, Fig. 5a), unshape-controlled alumina-silica with mesopores (AlMCM-41, Fig. 5b), spherical alumina-silica without pores $\left(\mathrm{sAl}_{2} \mathrm{O}_{3}-\mathrm{SiO}_{2}\right.$, Fig. 5c) and unshape-controlled alumina-silica without pores $\left(\mathrm{Al}_{2} \mathrm{O}_{3}-\mathrm{SiO}_{2}\right.$, Fig. 5d). The surface areas and pore diameters of the supports were characterized by $\mathrm{N}_{2}$ adsorption-desorption isotherms (Fig. 6). The isotherms obtained for sAlMCM-41 and AlMCM-41 were categorized to Type IV, which suggests mesoporous structures [45]. The pore diameters estimated by the MP method were about $1 \mathrm{~nm}$ for both samples. On the other hand, Type III isotherms obtained for both $\mathrm{sAl}_{2} \mathrm{O}_{3}-\mathrm{SiO}_{2}$ and $\mathrm{Al}_{2} \mathrm{O}_{3}-\mathrm{SiO}_{2}$ 
(a)

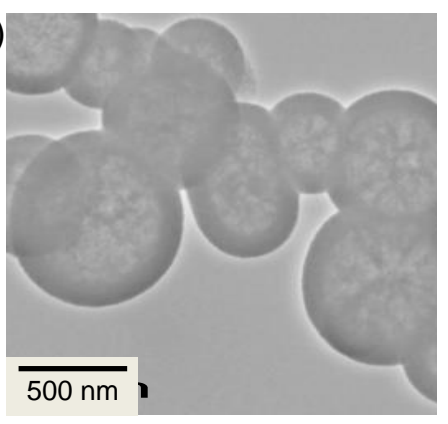

(c)

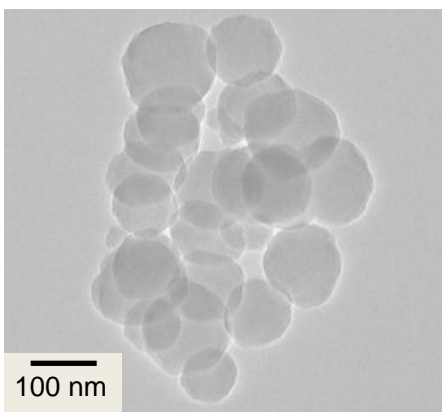

(b)

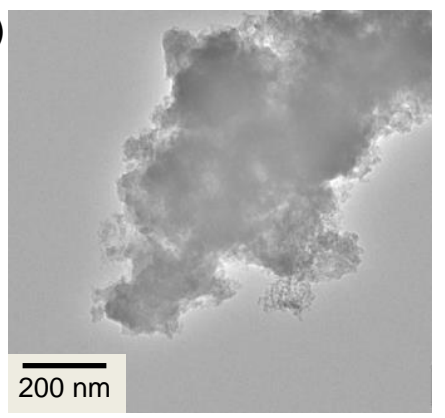

(d)

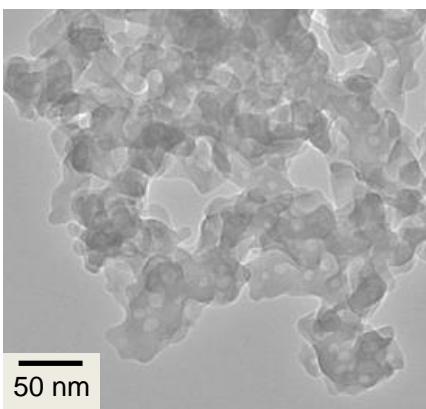

Fig. 5. TEM images of (a) sAlMCM-41, (b) AlMCM-41, (c) $\mathrm{sAl}_{2} \mathrm{O}_{3}-\mathrm{SiO}_{2} \mathrm{NP}$ and (d) $\mathrm{Al}_{2} \mathrm{O}_{3}-\mathrm{SiO}_{2}$.

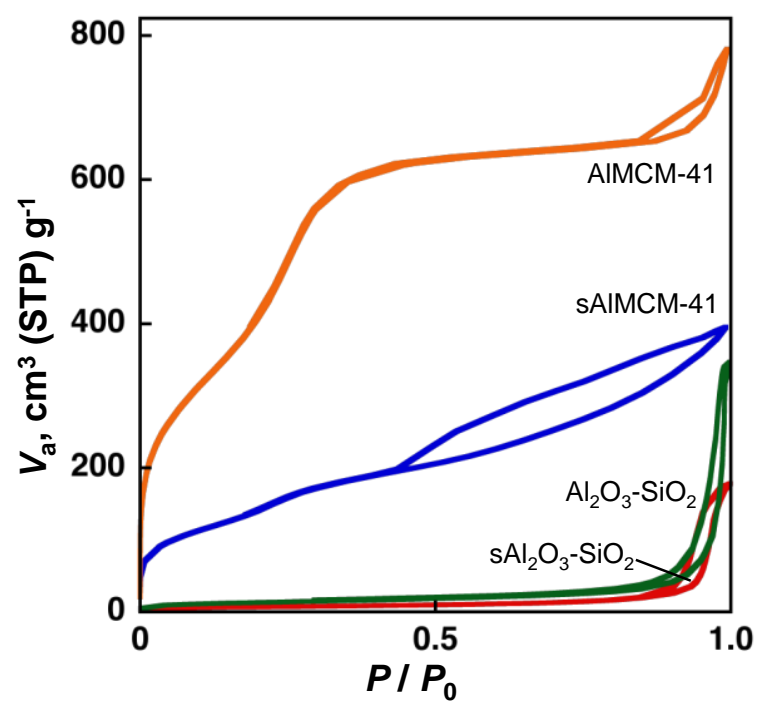

Fig. 6. Nitrogen adsorption-desorption isotherms of alumina-silica with various nanostructures and morphologies. [(a) sAlMCM-41 (blue), (b) AlMCM-41 (orange), (c) $\mathrm{sAl}_{2} \mathrm{O}_{3}-\mathrm{SiO}_{2}$ (red) and (d) $\mathrm{Al}_{2} \mathrm{O}_{3}-\mathrm{SiO}_{2}$ (green)] 
assured non-porous structure [45]. Table 1 summarizes the surface areas, pore sizes and adsorbed amount of $\mathrm{QuPh}^{+}-\mathrm{NA}$. The densities of $\mathrm{QuPh}^{+}-\mathrm{NA}$ on the surfaces of sAlMCM-41, AlMCM-41, $\mathrm{sAl}_{2} \mathrm{O}_{3}-\mathrm{SiO}_{2}$ and $\mathrm{Al}_{2} \mathrm{O}_{3}-\mathrm{SiO}_{2}$ were $0.17,0.04,0.80$ and 0.79 molecules $\mathrm{nm}^{-2}$, respectively, suggesting that $\mathrm{QuPh}^{+}-\mathrm{NA}$ molecules are isolated. The lower densities obtained for mesoporous alumina-silica may suggest that $\mathrm{QuPh}^{+}-\mathrm{NA}$ cannot penetrate deeply inside mesopores.

Table 1. Specific surface area and pore diameter, morphology and amount of $\mathrm{QuPh}^{+}-\mathrm{NA}$ adsorbed on alumina-silica.

\begin{tabular}{lcccc}
\hline Morphology & $\begin{array}{c}\text { BET } \\
\text { surface } \\
\text { area } \\
\left(\mathrm{m}^{2} \mathrm{~g}^{-1}\right)\end{array}$ & $\begin{array}{c}\text { Pore } \\
\text { diameter } \\
(\mathrm{nm})\end{array}$ & $\begin{array}{c}\mathrm{Amount}^{[\mathrm{a}]} \\
\mathrm{QuPh}^{+}-\mathrm{NA}^{[\mathrm{b}]} \\
\left(\mathrm{mol} \mathrm{g}^{-1}\right)\end{array}$ \\
\hline sAlMCM-41 & Spherical & 797 & 1.0 & $2.3 \times 10^{-4}$ \\
$\mathrm{AlMCM}-41$ & Unshaped & 1471 & 1.1 & $9.9 \times 10^{-5}$ \\
$\mathrm{sAl}_{2} \mathrm{O}_{3}-\mathrm{SiO}_{2}$ & Spherical & 24 & & $3.2 \times 10^{-5}$ \\
$\mathrm{Al}_{2} \mathrm{O}_{3}-\mathrm{SiO}_{2}$ & Unshaped & 47 & & $6.2 \times 10^{-5}$ \\
\hline
\end{tabular}

[a] determined by the MP method using desorption branch of $\mathrm{N}_{2}$-isohterm at $77 \mathrm{~K}$. [b] The loading amount of $\mathrm{QuPh}^{+}-\mathrm{NA}$ was calculated from decrease in absorbance at $333 \mathrm{~nm}$ characteristic of $\mathrm{QuPh}^{+}-\mathrm{NA}$ caused by the addition of alumina-silica to mother liquor.

Activity of the composite catalysts employing these four alumina-silica supports was examined for photocatalytic $\mathrm{H}_{2}$ evolution in a phthalate buffer together with oxalate anion (50 $\mathrm{mM})$ and $\mathrm{Pt}^{\mathrm{IV}} \mathrm{Cl}_{6}{ }^{2-}$. The amounts of used catalysts were normalized by the concentration of $\mathrm{QuPh}^{+}-\mathrm{NA}$ to be $0.22 \mathrm{mM}$. Fig. 7 shows the time courses of $\mathrm{H}_{2}$ evolution from the reaction suspensions under photoirradiation. The fastest initial $\mathrm{H}_{2}$ evolution $\left(0.83 \mu \mathrm{mol} \mathrm{h}^{-1}\right)$ was obtained for the composite catalyst using sAlMCM-41, however, the $\mathrm{H}_{2}$ evolution was ceased after photoirradiation for $10 \mathrm{~h}$. The composite catalyst employing AlMCM-41 as a support exhibited slower $\mathrm{H}_{2}$ evolution $\left(0.22 \mu \mathrm{mol} \mathrm{h}^{-1}\right)$ with the amount less than $5 \mu \mathrm{mol}$. Composite catalyst using non-porous $\mathrm{SAl}_{2} \mathrm{O}_{3}-\mathrm{SiO}_{2}$ 


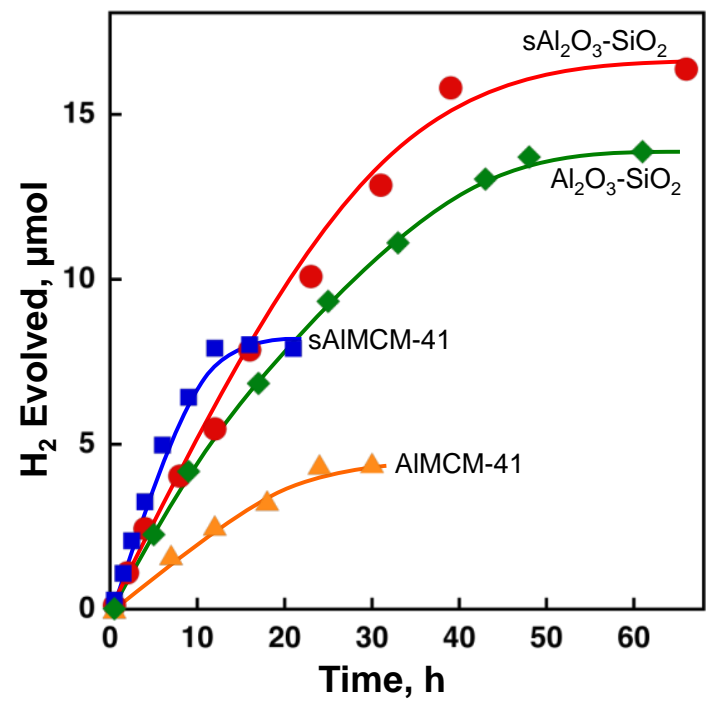

Fig. 7. Time courses of $\mathrm{H}_{2}$ evolution under photoirradiation $(\lambda>340 \mathrm{~nm})$ of a deaerated mixed solution $(2.0 \mathrm{~mL})$ of a phthalate buffer $(\mathrm{pH} 4.5)$ containing $\mathrm{K}_{2} \mathrm{PtCl}_{6}(0.055 \mathrm{mM}),(\mathrm{COONa})_{2}(50$ $\mathrm{mM})$ and $\mathrm{QuPh}^{+}-\mathrm{NA} @$ silica-alumina $\left(\left[\mathrm{QuPh}^{+}-\mathrm{NA}\right]=0.22 \mathrm{mM} ; \mathrm{QuPh}^{+}-\mathrm{NA} @\right.$ sAlMCM-41, 5.0 mg, blue square; $\mathrm{QuPh}^{+}-\mathrm{NA} @ \mathrm{AlMCM}-41,4.4 \mathrm{mg}$, orange triangle; $\mathrm{QuPh}^{+}-\mathrm{NA} @ \mathrm{SAl}_{2} \mathrm{O}_{3}-\mathrm{SiO}_{2}$, $13.6 \mathrm{mg}$, red circle; $\mathrm{QuPh}^{+}-\mathrm{NA} @ \mathrm{Al}_{2} \mathrm{O}_{3}-\mathrm{SiO}_{2}, 7.1 \mathrm{mg}$, green diamond) at $298 \mathrm{~K}$.

and $\mathrm{Al}_{2} \mathrm{O}_{3}-\mathrm{SiO}_{2}$ as supports exhibited slower initial $\mathrm{H}_{2}$ evolution compared with the catalyst using sAlMCM-41, however, higher durability was achieved as evidenced by the larger amount of $\mathrm{H}_{2}$ evolution (16 and $13 \mu \mathrm{mol}$, respectively), which are more than double that of sAlMCM-41. These results suggest that the mesoporous silica-alumina is not a suitable support for constructing an active composite catalyst although reasons are unclear.

The effect of the loading amount of $\mathrm{QuPh}^{+}-\mathrm{NA}$ on a silica-alumina support was investigated. Photocatalytic $\mathrm{H}_{2}$ evolution was performed by photoirradiation of a suspension containing $\mathrm{K}_{2} \mathrm{PtCl}_{6},(\mathrm{COONa})_{2}$ and $\mathrm{QuPh}^{+}-\mathrm{NA} @ \mathrm{Al}_{2} \mathrm{O}_{3}-\mathrm{SiO}_{2}\left(12.9 \mathrm{mg},\left[\mathrm{QuPh}^{+}-\mathrm{NA}\right]=0.22 \mathrm{mM}\right)$, which was prepared by decreasing the loading amount of $\mathrm{QuPh}^{+}-\mathrm{NA}$ on $\mathrm{Al}_{2} \mathrm{O}_{3}-\mathrm{SiO}_{2}$ from 64 to 34 $\mu \mathrm{mol} \mathrm{g}^{-1}$ as shown in Fig. 8. Although the concentrations of $\mathrm{QuPh}^{+}-\mathrm{NA}$ are the same in the reaction suspensions, reactivity of the $\mathrm{Al}_{2} \mathrm{O}_{3}-\mathrm{SiO}_{2}$ loading a small amount of $\mathrm{QuPh}^{+}-\mathrm{NA}$ was 


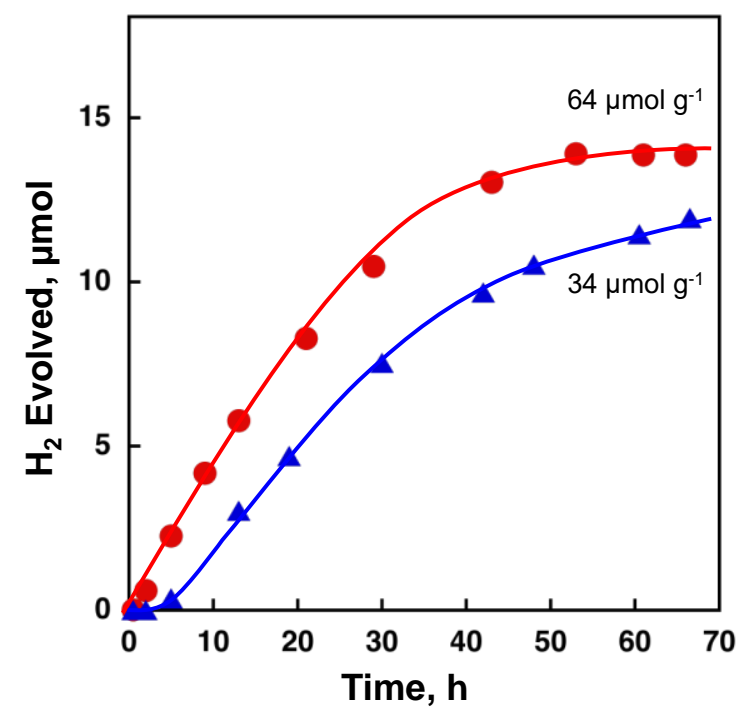

Fig. 8. Time courses of $\mathrm{H}_{2}$ evolution under photoirradiation $(\lambda>340 \mathrm{~nm})$ of a deaerated phthalate buffer $(\mathrm{pH} 4.5,2.0 \mathrm{~mL})$ containing $\mathrm{K}_{2} \mathrm{PtCl}_{6}(0.055 \mathrm{mM})$, $(\mathrm{COONa})_{2}(50 \mathrm{mM})$ and different amounts of $\mathrm{QuPh}^{+}-\mathrm{NA} @ \mathrm{Al}_{2} \mathrm{O}_{3}-\mathrm{SiO}_{2}\left[7.1 \mathrm{mg}\left(\left[\mathrm{QuPh}^{+}-\mathrm{NA}\right]=0.22 \mathrm{mM}, 64 \mu \mathrm{mol} \mathrm{g}^{-1}\right)\right.$, red circle; $12.9 \mathrm{mg}\left(\left[\mathrm{QuPh}^{+}-\mathrm{NA}\right]=0.22 \mathrm{mM}, 34 \mu \mathrm{mol} \mathrm{g}^{-1}\right)$, blue triangle $]$.

slightly lower than that loading a large amount of $\mathrm{QuPh}^{+}-\mathrm{NA}$. These results suggest that the catalysis of the composite catalyst may be improved by employing an optimum density of $\mathrm{QuPh}^{+}-\mathrm{NA}$ on the surfaces of alumina-silica.

\subsection{Composite catalysts using $\mathrm{Ru}, \mathrm{Cu}$ and $\mathrm{Ni}$ as $\mathrm{H}_{2}$-evolution catalysts}

Other than $\mathrm{Pt}$, nanoparticles of $\mathrm{Ru}, \mathrm{Fe}$ and $\mathrm{Ni}$ have been reported to act as $\mathrm{H}_{2}$-evolution catalysts $[36,38,46]$. Thus, the photocatalytic $\mathrm{H}_{2}$ evolution was conducted in an aqueous buffer ( $\mathrm{pH}$ 4.5) containing $\mathrm{QuPh}^{+}-\mathrm{NA} @ \mathrm{sAlMCM}-41$ and oxalic acid in the presence of $\mathrm{Ru}^{3+}, \mathrm{Fe}^{2+}$, $\mathrm{Cu}^{2+}, \mathrm{Ni}^{2+}$ or $\mathrm{Co}^{2+}$ ions in the form of $\mathrm{RuCl}_{3}, \mathrm{FeSO}_{4}, \mathrm{Cu}\left(\mathrm{NO}_{3}\right)_{2}, \mathrm{Ni}\left(\mathrm{NO}_{3}\right)_{2}$ or $\mathrm{Co}\left(\mathrm{NO}_{3}\right)_{2}$, respectively. The time courses of $\mathrm{H}_{2}$ evolution shown in Fig. 9 exhibited that the $\mathrm{H}_{2}$-evolution 


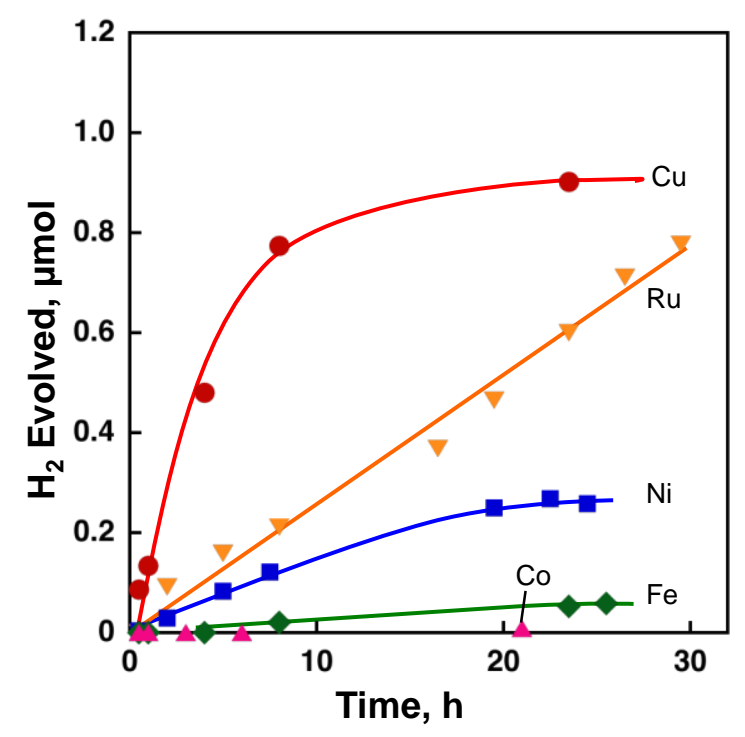

Fig. 9. Time courses of $\mathrm{H}_{2}$ evolution under photoirradiation $(\lambda>340 \mathrm{~nm})$ of a deaerated phthalate buffer $(\mathrm{pH} 4.5)$ containing $\mathrm{QuPh}^{+}-\mathrm{NA} @$ sAlMCM-41 $\left(5.0 \mathrm{mg},\left[\mathrm{QuPh}^{+}-\mathrm{NA}\right]=0.22\right.$ $\mathrm{mM})$ and $(\mathrm{COONa})_{2}(50 \mathrm{mM})$ with various metal salts $\left[0.055 \mathrm{mM} ; \mathrm{Cu}\left(\mathrm{NO}_{3}\right)_{2}\right.$, red circle; $\mathrm{RuCl}_{3}$, orange inverse triangle; $\mathrm{Ni}\left(\mathrm{NO}_{3}\right)_{2}$, blue square; $\mathrm{FeSO}_{4}$, green diamond; $\mathrm{Co}\left(\mathrm{NO}_{3}\right)_{2}$, pink triangle].

rate for the reaction system containing $\mathrm{Cu}^{2+}$ ions was $0.11 \mu \mathrm{mol} \mathrm{h}^{-1}$, which is larger than those containing $\mathrm{Ru}^{3+}\left(0.03 \mu \mathrm{mol} \mathrm{h}{ }^{-1}\right), \mathrm{Ni}^{2+}\left(0.02 \mu \mathrm{mol} \mathrm{h}^{-1}\right), \mathrm{Fe}^{2+}\left(<0.01 \mu \mathrm{mol} \mathrm{h}{ }^{-1}\right)$ or $\mathrm{Co}^{2+}(<0.01$ $\mu \mathrm{mol} \mathrm{h} \mathrm{h}^{-1}$ ) ions. $\mathrm{Cu}$ nanoparticles without a support has been reported to act as an inferior $\mathrm{H}_{2}$ evolution catalyst to $\mathrm{Ru}$ and Ni nanoparticles [38]. This is probably due to easy agglomeration properties of $\mathrm{Cu}$ nanoparticles, which can be suppressed by being loaded on sAlMCM-41. For example, the durability of $\mathrm{Ru}$ nanoparticles has been reported to be much improved by loading $\mathrm{Ru}$ nanoparticles on a silica support in comparison with that of unsupported $\mathrm{Ru}$ nanoparticles [39]. Thus, loading of $\mathrm{Cu}$ particles on a metal oxide support may also prevent agglomeration of $\mathrm{Cu}$ nanoparticles, leading to high catalytic activity.

The effect of concentration of $\mathrm{Cu}$ ions in the reaction suspension on the $\mathrm{H}_{2}$ evolution was examined by changing the concentrations from $0.027 \mathrm{mM}$ to $0.55 \mathrm{mM}$ (Fig. 10). The fastest $\mathrm{H}_{2}$ 


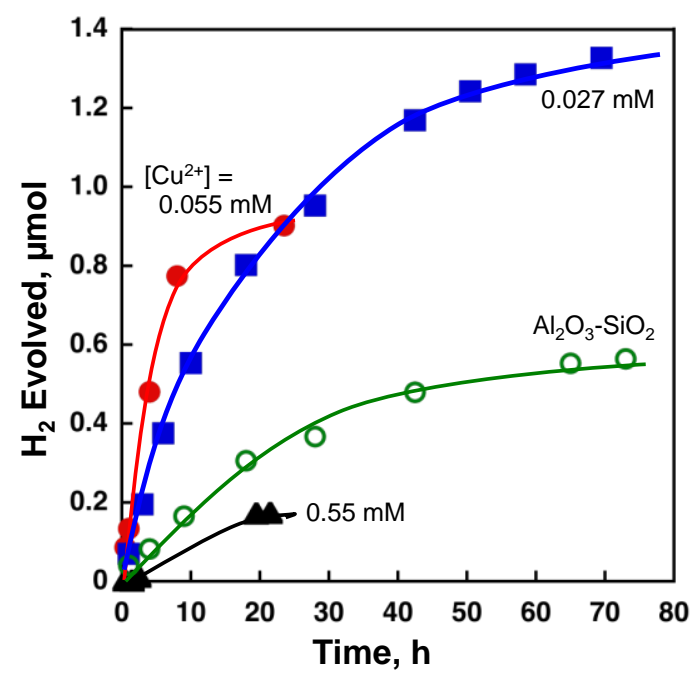

Fig. 10. Time courses of $\mathrm{H}_{2}$ evolution under photoirradiation $(\lambda>340 \mathrm{~nm})$ of a deaerated phthalate buffer $(\mathrm{pH} 4.5)$ containing $\mathrm{QuPh}^{+}-\mathrm{NA} @ \mathrm{sAlMCM}-41\left(5.0 \mathrm{mg},\left[\mathrm{QuPh}^{+}-\mathrm{NA}\right]=0.22\right.$ $\mathrm{mM})$ and $(\mathrm{COONa})_{2}(50 \mathrm{mM})$ with $\mathrm{Cu}\left(\mathrm{NO}_{3}\right)_{2}[0.55 \mathrm{mM}$ (black triangle), $0.055 \mathrm{mM}$ (red circle) or $0.027 \mathrm{mM}$ (blue square)] and $\mathrm{QuPh}^{+}-\mathrm{NA} @ \mathrm{Al}_{2} \mathrm{O}_{3}-\mathrm{SiO}_{2}\left(7.1 \mathrm{mg},\left[\mathrm{QuPh}^{+}-\mathrm{NA}\right]=0.22 \mathrm{mM}\right)$ and $(\mathrm{COONa})_{2}(50 \mathrm{mM})$ with $\mathrm{Cu}\left(\mathrm{NO}_{3}\right)_{2}(0.055 \mathrm{mM})$ (green open circle).

evolution was observed for the reaction suspension containing $\mathrm{QuPh}^{+}-\mathrm{NA} @$ sAlMCM-41 and Cu ion in the concentration of $0.055 \mathrm{mM}$, however, the total amount of evolved $\mathrm{H}_{2}$ was smaller than $1.0 \mu \mathrm{mol}$. More than $1.3 \mu \mathrm{mol} \mathrm{H}_{2}$ was obtained from the reaction suspension containing $\mathrm{Cu}$ ion in the concentration of $0.027 \mathrm{mM}$ although the $\mathrm{H}_{2}$-evolution rate was moderate $\left(0.06 \mu \mathrm{mol} \mathrm{h}^{-1}\right)$. When the concentration of $\mathrm{Cu}$ ion was increased to $0.55 \mathrm{mM}$, the total amount of evolved $\mathrm{H}_{2}$ decreased to less than $0.2 \mu \mathrm{mol}$ with slow $\mathrm{H}_{2}$ evolution. The deceleration tendency observed for $\mathrm{Cu}$ ion is similar to that observed for the composite catalysts prepared with $\mathrm{PtCl}_{6}{ }^{2-}$ as shown in Fig. 1. At high concentrations, metal particles probably grew too many or too large to form an efficient composite catalyst in the mesopores of the mesoporous alumina-silica (sAlMCM-41). When the concentration of $\mathrm{Cu}\left(\mathrm{NO}_{3}\right)_{2}$ was $0.055 \mathrm{mM}$, nanoparticles with a suitable number and size for $\mathrm{H}_{2}$ evolution formed at first, and then, grew too many or too large. Size dependence of nanoparticles on photocatalytic $\mathrm{H}_{2}$ evolution has been also reported for $\mathrm{Ru}$ nanoparticles without 
a support [36]. Similarly, higher catalytic activity was obtained at lower concentrations of a $\mathrm{Ni}^{2+}$ precursor in the reaction suspensions as shown in Fig. S1.

Alumina-silica supports with non-porous structures are beneficial for improving reactivity of the composite catalysts loading $\mathrm{Pt}$ in terms of the $\mathrm{H}_{2}$ yield (vide supra). Thus, a composite catalyst with alumina-silica with a non-porous structure $\left(\mathrm{Al}_{2} \mathrm{O}_{3}-\mathrm{SiO}_{2}\right)$ was prepared by photoirradiation of an aqueous buffer containing $\mathrm{QuPh}^{+}-\mathrm{NA} @ \mathrm{Al}_{2} \mathrm{O}_{3}-\mathrm{SiO}_{2}, \mathrm{Cu}\left(\mathrm{NO}_{3}\right)_{2}$ and oxalate. On the contrary to the composite catalysts loading Pt, non-porous $\mathrm{Al}_{2} \mathrm{O}_{3}-\mathrm{SiO}_{2}$ loading $\mathrm{Cu}$ exhibited low catalytic activity in terms of the $\mathrm{H}_{2}$-evolution rate and $\mathrm{H}_{2}$ yield (Fig. 10, green open circle). Although $\mathrm{Cu}$ particles were not clearly observed by conventional TEM measurements, $\mathrm{Cu}$ particles may grow too large more than suitable size for $\mathrm{H}_{2}$ evolution at the lower surface area support due to its easy agglomeration properties.

The effects of precursors for $\mathrm{Cu}$ nanoparticles were examined on the photocatalytic $\mathrm{H}_{2}$ evolution, because composite catalysts prepared in an aqueous buffer containing Pt precursors exhibited large difference in catalytic activity depending on the electric charge of precursors (vide supra). $\mathrm{Cu}\left(\mathrm{NO}_{3}\right)_{2}$ and $\mathrm{K}_{2} \mathrm{CuCl}_{4}$ were employed as cationic and anionic precursors for preparing composite catalysts, respectively. However, no significant difference was observed for these two reaction systems (Fig. 11a). Similar catalytic activity obtained for the reaction systems employing $\mathrm{Cu}\left(\mathrm{NO}_{3}\right)_{2}$ and $\mathrm{K}_{2} \mathrm{CuCl}_{4}$ was ascribed to the labile property of the $\mathrm{Cu}$ precursors. The addition of oxalate to the solution containing $\mathrm{K}_{2} \mathrm{CuCl}_{4}$ induced the shift of $\mathrm{UV}$-vis absorption maxima from 750 to $700 \mathrm{~nm}$, indicating that oxalate coordinate to $\mathrm{Cu}^{2+}$ ion of $\mathrm{K}_{2} \mathrm{CuCl}_{4}$ to form an oxalate complex (Fig. 11b). The same absorption maxima in UV-vis spectrum observed for a buffer containing $\mathrm{Cu}\left(\mathrm{NO}_{3}\right)_{2}$ and oxalic acid suggests that the structure of $\mathrm{Cu}$ species formed in the reaction solution is identical to that of $\mathrm{K}_{2} \mathrm{CuCl}_{4}$ and oxalic acid in the reaction suspension 
(a)

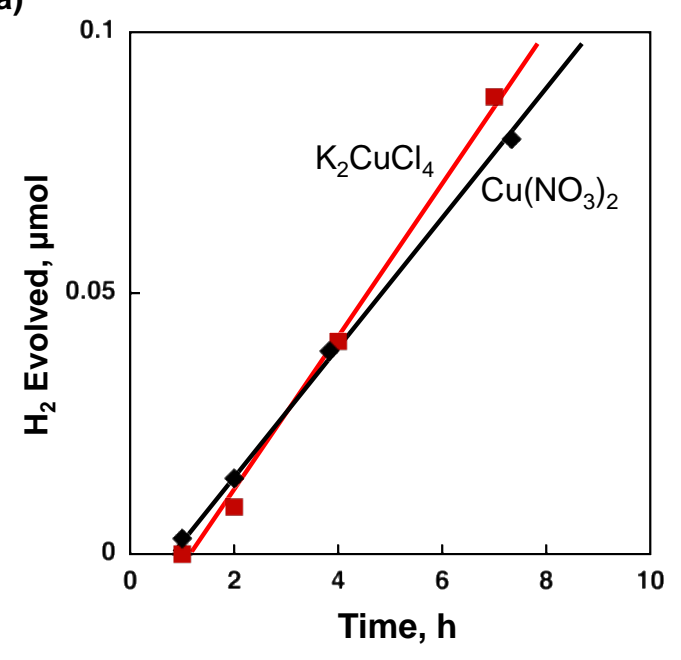

(b)

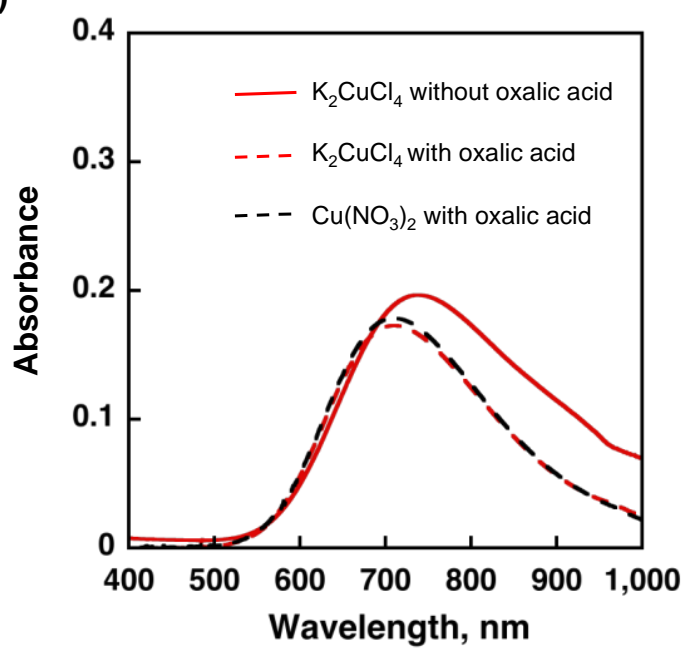

Fig. 11. (a) Time courses of $\mathrm{H}_{2}$ evolution under photoirradiation $(\lambda>340 \mathrm{~nm})$ of a deaerated phthalate buffer $(\mathrm{pH} 4.5)$ containing $\mathrm{QuPh}^{+}-\mathrm{NA} @ \mathrm{Al}_{2} \mathrm{O}_{3}-\mathrm{SiO}_{2}\left(7.1 \mathrm{mg},\left[\mathrm{QuPh}^{+}-\mathrm{NA}\right]=0.22\right.$ $\mathrm{mM})$ and $(\mathrm{COONa})_{2}(50 \mathrm{mM})$ with $\mathrm{Cu}\left(\mathrm{NO}_{3}\right)_{2}$ (black) or $\mathrm{K}_{2} \mathrm{CuCl}_{4}$ (red) $(0.055 \mathrm{mM})$. (b) UV-vis spectral change by addition of oxalic acid to a phthalate buffer containing $\mathrm{Cu}\left(\mathrm{NO}_{3}\right)_{2}$ (black) or $\mathrm{K}_{2} \mathrm{CuCl}_{4}$ (red). The solid line was obtained for the solution in the absence of oxalic acid and the dashed lines in the presence of oxalic acid.

before photoirradiation. Catalysis measurements of the reaction systems using a precursor for $\mathrm{Cu}$ particles selected from $\mathrm{Cu}\left(\mathrm{CF}_{3} \mathrm{SO}_{3}\right)_{2}, \mathrm{Cu}\left(\mathrm{ClO}_{4}\right)_{2}, \mathrm{~K}_{2} \mathrm{CuCl}_{4}, \mathrm{Cu}_{2}(\mathrm{OAc})_{4}\left(\mathrm{H}_{2} \mathrm{O}\right)_{2},\left[\mathrm{Cu}(\mathrm{bpy})_{2}\right]^{2+}$ and $\left[\mathrm{Cu}(\mathrm{MeObpy})_{2}\right]^{2+}$ also manifested that the catalytic activity of the composite catalysts is independent of precursors (Fig. S2).

\section{Conclusion}

Composite catalysts for photocatalytic $\mathrm{H}_{2}$ evolution were prepared by in situ reduction of a Pt complex by utilizing the photocatalysis of $\mathrm{QuPh}^{+}-\mathrm{NA}$ supported on the surfaces of aluminasilica. The in-situ reduction allows to accommodate $\mathrm{Pt}$ nanoparticles close to $\mathrm{QuPh}^{+}-\mathrm{NA}$ on the support surfaces. For efficient $\mathrm{H}_{2}$ evolution, selection of the precursor is important because positively charged precursors interact with negatively charged alumina-silica surfaces rather than 
positively charged $\mathrm{QuPh}^{+}-\mathrm{NA}$. Additionally, the suitable choices of the precursor concentration and morphology of a support are important to achieve high catalytic activity. By employing in situ-reduction procedure, $\mathrm{Cu}$ particles have been proved to act as an $\mathrm{H}_{2}$-evolution catalyst. However, no significant dependence of precursors on photocatalytic $\mathrm{H}_{2}$ evolution because oxalate, which was used as an electron donor, readily form a kinetically rather stable complex with $\mathrm{Cu}$ ion. The finding disclosed here is beneficial to achieve highly active composite catalysts developed for artificial photosynthesis on a metal oxide support.

\section{Acknowledgements}

This work was supported by JSPS KAKENHI (Nos. 24350069 and 15K14223 to Y.Y.) for

Scientific Research from Japan Society for the Promotion of Science (JSPS). We sincerely acknowledge the Research Center for Ultra-Precision Science \& Technology, Osaka University for TEM measurements.

\section{Appendix A. Supplementary content}

Supplementary contents associated with this article can be found, in the online version, at http://dx.doi.org/10.1016/j.cattod. XXXXX.

\section{References}

[1] H. B. Gray, H. B., Nat. Chem. 1 (2009) 7.

[2] D. Gust, T. A. Moore, A. L. Moore, Acc. Chem. Res. 42 (2009) 1890-1898.

[3] D. G. Nocera, Acc. Chem. Res. 45 (2012) 767-776.

[4] J. M. Thomas, Energy Environ. Sci. 7 (2014) 19-20.

[5] T. A. Faunce, W. Lubitz, A. W. Rutherford, D. MacFarlane, G. F. Moore, P. Yang, D. G. Nocera, T. A. Moore, D. H. Gregory, S. Fukuzumi, K. B. Yoon, F. A. Armstrong, M. R. Wasielewski, S. Styring, Energy Environ. Sci. 6 (2013) 695.

[6] A. Fujishima, K. Honda, Nature 238 (1972) 37.

[7] A. Fujishima, X. Zhang, D. A. Tryk, Int. J. Hydrogen Energy 32 (2007) 2664-2672.

[8] F. E. Osterloh, Chem. Soc. Rev. 42 (2013) 2294-2320.

[9] A. Kudo, Y. Miseki, Chem. Soc. Rev. 38 (2009) 253-278.

[10] T. Hisatomi, J. Kubota, K. Domen, Chem. Soc. Rev. 3 (2014) 1486-1503. 
[11] K. Maeda, K. Teramura, D. Lu, T. Takata, N. Saito, Y. Inoue, K. Domen, Nature 440 (2006) 295.

[12] L. Z. Wu, B. Chen, Z. J. Li, C. H. Tung, Acc. Chem. Res. 47 (2014) 2177-2185.

[13] S. Berardi, S. Drouet, L. Francàs, C. Gimbert-Suriñach, M. Guttentag, C. Richmond, T. Stolla, A. Llobet, Chem. Soc. Rev. 43 (2014) 7501-7519.

[14] M. D. Kärkäs, E. V. Johnston, O. Verho, B. Åkermark, Acc. Chem. Res. 47 (2014) 100111.

[15] Z. Han, R. Eisenberg, Acc. Chem. Res. 47 (2014) 2537-2544.

[16] H. Ozawa, K. Sakai, Chem. Commun. 47 (2011) 2227-2242.

[17] S. Fukuzumi, Y. Yamada, T. Suenobu, K. Ohkubo, H. Kotani, Energy Environ. Sci. 4 (2011) 2754-2766.

[18] M. Wang, Y. Na, M. Gorlov, L. Sun, Dalton Trans. (2009) 6458-6467.

[19] S. Fukuzumi, Eur. J. Inorg. Chem. (2008) 1351-1362.

[20] A. J. Esswein, D. G. Nocera, Chem. Rev. 107 (2007) 4022-4047.

[21] J. Kiwi, M. Gratzel, Nature 281 (1979) 657-658.

[22] K. Kalyanasundaram, J. Kiwi, M. Grätzel, Helv. Chim. Acta 61 (1978) 2720-2730.

[23] J. M. Lehn, J. P. Sauvage, New J. Chem. 1 (1977) 449-451.

[24] M. D. Kärkäs, O. Verho, E. V. Johnston, B. Åkermark, Artificial Photosynthesis: Molecular Systems for Catalytic Water Oxidation. Chem. Rev. 114 (2014) 1186312001.

[25] A. R. Parent, K. Sakai, ChemSusChem 7 (2014) 2070-2080.

[26] S. Fukuzumi, D. Hong, Eur. J. Inorg. Chem. (2014) 645-659.

[27] X. Sala, S. Maji, R. Bofill, J. Garia-Anton, L. S. Escriche, A. Llobet, Acc. Chem. Res. 47 (2014) 504-516.

[28] S. Fukuzumi, Y. Yamada, J. Mater. Chem. 22 (2012) 24284-24296.

[29] T. R. Cook, D. K. Dogutan, S. Y. Reece, Y. Surendranath, T. S. Teets, D. G. Nocera, Chem. Rev. 110 (2010) 6474-6502.

[30] S. Fukuzumi, D. Hong, Y. Yamada, J. Phys. Chem. Lett. 4 (2013) 3458-3467.

[31] S. Fukuzumi, Y. Yamada, ChemSusChem 6 (2013) 1834-1847.

[32] J. Dasgupta, G. M. Ananyev, G. C. Dismukes, Coord. Chem. Rev. 252 (2008) 347-360.

[33] J. H. Alstrum-Acevedo, M. K. Brennaman, T. J. Meyer, Inorg. Chem. 44 (2005) 68026827.

[34] Y. Yamada, H. Tadokoro, S. Fukuzumi, RSC Adv. 3 (2013) 25677-25680.

[35] H. Kotani, K. Ohkubo, S. Fukuzumi, Faraday Discuss. 155 (2012) 89-102.

[36] Y. Yamada, T. Miyahigashi, H. Kotani, K. Ohkubo, S. Fukuzumi, J. Am. Chem. Soc. 133 (2011) 16136-16145.

[37] Y. Yamada, T. Miyahigashi, K. Ohkubo, S. Fukuzumi, Phys. Chem. Chem. Phys. 14 (2012) 10564-10571.

[38] Y. Yamada, T. Miyahigashi, H. Kotani, K. Ohkubo, S. Fukuzumi, Energy Environ. Sci. 5 (2012) 6111-6118.

[39] Y. Yamada, S. Shikano, S. Fukuzumi, J. Phys. Chem. C 117 (2013) 13143-13152.

[40] Y. Yamada, S. Shikano, S. Fukuzumi, RSC Adv. 5 (2015) 44912-44919.

[41] Y. Yamada, A. Nomura, H. Tadokoro, S. Fukuzumi, Catal. Sci. Technol. 5 (2015) 428437.

[42] Y. Yamada, S. Shikano, T. Akita, S. Fukuzumi, Catal. Sci. Technol. 5 (2015) 979-988.

[43] K. Sakai, Y. Kizaki, T. Tsubomura, K. Matsumoto, J. Mol. Catal. 79 (1993) 141-152. 
[44] R. C. Weast, in Handbook of Chemistry and Physics, CRC, Cleaveland, OH, 56th ed., 1975-1976.

[45] K. S. W. Sing, D. H. Everett, R. A. W. Haul, L. Moscou, R. A. Pierotti, J. Rouquerol, T. Siemieniewska, Pure Appl. Chem. 57 (1985) 603-619.

[46] H. Kotani, R. Hanazaki, K. Ohkubo, Y. Yamada, S. Fukuzumi, Chem. Eur. J. 17 (2011) 2777-2785. 